\title{
PAULINA SZKUDLAREK
}

(Poznań)

\section{KRYZYS SEMIOTYKI STRUKTURALISTYCZNEJ I PRÓBY JEGO PRZEZWYCIĘŻENIA W PÓŹNYCH KONCEPCJACH A.-J. GREIMASA I U. ECO}

Już od momentu wprowadzenia dyscypliny do naukowego dyskursu, nie było „jednej semiotyki”, tym bardziej więc nie mieliśmy do czynienia z późniejszym jednotorowym rozwojem. Nietrudno zatem wskazać na rozmaite podziały porządkujące interesującą mnie myśl. Spośród trzech, które chciałabym przywołać, pierwszy wyodrębnia semiotykę ufundowaną przez Charlesa S. Peirce'a, zwaną semiotyką filozoficzną, oraz semiotykę strukturalistyczną, która za podstawę przyjęła i zaadoptowała dla swych celów językoznawstwo Ferdinanda de Saussure'a. Drugie rozróżnienie, dokonane przez Algirdasa-Juliena Greimasa, ujmuje semiotykę bądź jako logiczną racjonalność zastosowaną do uniwersum zjawiska znaczenia ${ }^{1}$, bądź jako zbiór sygnałów znaczących, gdzie elementy charakteryzują się autonomiczną organizacją wewnętrzną. To, odpowiednio, sémiotique-sujet oraz sémiotique-objet.

W. Hammerstingl, badający semiotykę jako teorię komunikacji, uszczegółowił podział Greimasa, proponując rozróżnienie na

- semiotykę deskryptywną, opisujaccą jedynie fenomeny znakowe,

- semiotykę teoretyczną, systematyzujaccą owe opisy w celu budowania modeli, formułowania teorii,

- semiotykę stosowaną, dokonującą implikacji tej wiedzy, czyniącą ją narzędziem w nauce, społeczeństwie, życiu codziennym.

Częściowo koresponduje to ze ścieżką rozwoju koncepcji w szkole moskiewsko-tartuskiej, należącej do semiotyki strukturalistycznej. Teraz jednak przedmiotem mojego zainteresowania będzie zakorzeniona - za pośrednictwem Hjelmsleva i Lévi-

1 G. Bucher, Od doskonalości teorii do niedoskonałości pisarstwa, przeł. W. Wilczyńska, w: Idac za Greimasem, red. A. Grzegorczyk i M. Loba, Humaniora, Poznań 1998, s. 203. 
-Straussa - w tym samym nurcie myśl Greimasa właśnie. Na przestrzeni kilku dziesięcioleci stworzył on potężne instrumentarium pojęciowe usytuowane w obrębie rygorystycznie ustrukturyzowanego systemu, który ujmuje kulturę w kategoriach naukowej semiotyki strukturalistycznej, czy raczej neostrukturalistycznej. Najistotniejsze narzędzie wypracowane w tych ramach, a służące nadrzędnemu celowi dyscypliny, jakim jest typologia dyskursów ${ }^{2}$, stanowi tu nazwany przez Sewerynę Wysłouch „magicznym”, kwadrat opisujący byt i działanie na zasadzie opozycji, implikacji i dysjunkcji. Koncepcje te okazały się wpływowe i inspirujące dla licznego grona uczniów autora Du sens, skupionych wokół „Actes Sémiotiques” (potem: „Nouveaux Actes Sémiotiques”). Co zatem oczywiste, zdziwienie, by nie powiedzieć - dezorientację wywołała stosunkowo skromna objętościowo praca powstała w siedemdziesiątym roku życia Greimasa, O niedoskonałości ${ }^{3}$. Badacz, który wcześniej rozpisywał na formalne schematy mityczne opowieści ${ }^{4}$, zaskoczył odbiorców zbiorem impresyjnych esejów zainspirowanych fragmentami rozmaitych dzieł literackich, np. Cortazara czy Tourniera. Dotyczą one-jak ujął to G. Bucher - „namiętności przeżywanej w twórczej aisthesis czyli tajemnicy poesis” i starają się zgłębić sekret istoty Zdarzenia Literackiego ${ }^{5}$. Kilkanaście lat wcześniej, w Essai de sémiotique poétique (1972), Greimas deklarował, iż „obiekty poetyckie”, jakie chciałaby wypracować semiotyka, to tylko „przedmioty skonstruowane”, nie mogące oddać pełni »przeżycia« w swej tekstowej postaci, a język stworzony dla wyrażenia zrozumialności owych obiektów, sam poetyckim być nie może ${ }^{6}$.

Tymczasem O niedoskonałości - eseje o pięknie ${ }^{7}$ - jest nie tylko pięknie napisane, lecz poza tym, jak czytamy w wzmiance umieszczonej na stronie tytułowej polskiego wydania, w oryginale De l'imperfection było bibliofilską edycją na welinie. Sama książka była zatem pomyślana jako piękny przedmiot.

Zainteresowanie stosunkiem podmiotu do doznania zmysłowego widoczne jest też w Sémiotique des passions, również pochodzącej z późnego okresu twórczości Greimasa. Tłumacz O niedoskonałości na język hiszpański, Raul Dorra, uznał rozprawę napisaną przez Greimasa wspólnie z Jacquesem Fontanillem za niejako

\footnotetext{
2 Za: C. Zilberberg, Semiotyka, epistemologia i negatywność, przeł. M. Loba, w: Idacc za Greimasem, wyd. cyt., s. 148.

3 A.-J. Greimas, O niedoskonałości, przeł. A. Grzegorczyk, Wydawnictwo Naukowe UAM, Poznań 1993.

4 A.-J. Greimas, Ku teorii interpretacji opowiadania mitycznego, przeł. A. Grzegorczyk i E. Umińska-Plisenko, w: A.-J. Greimas, E. Leach, Rytuat i narracja, przeł. M. Buchowski, A. Grzegorczyk, E. Umińska-Plisenko, PWN, Warszawa 1989.

5 G. Bucher, Od doskonatości..., wyd. cyt., s. 201.

6 Za: tamże, s. 202.

7 „[N]ieregularność (...) coś nieoczekiwanego (...) stanowią istotny składnik charakterystyki piękna" - napisał, przytaczany zreszta przez Greimasa, Charles Baudelaire (Fusées). Za: A.-J. Greimas, O niedoskonatości, wyd. cyt., s. 109.
} 
komplementarną wobec poetyckich esejów przeznaczonych nie tyle do analizy, co do kontemplacji ${ }^{8}$. Wedle argentyńskiego literaturoznawcy, Sémiotique des passions okazała się rozwiązaniem licznych problemów, pour ainsi dire, metodologicznych, jakie ewokowało O niedoskonałości. Oto w myśli Greimasa nadszedł moment zmiany koncepcji nauki, by uczynić ją odpowiednią dla traktowania zdarzenia estetycznego jako spotkania subiektywności z rzeczywistością sensualną ${ }^{9}$.

Wspólnym mianownikiem obu rozważanych prac miałaby być próba przezwyciężenia obserwowalnego we współczesności zatracania się znaczenia. Odnowa jest z kolei konieczna z tego prostego powodu, iż bez niej semiotyka jako „logiczna racjonalność stosowana do uniwersum zjawiska znaczenia" byłaby pozbawiona swego raison d'être. Bezznaczeniowość, albo, by użyć synonimu mającego w języku polskim silniejszą wymowę, bezsens przestrzeni egzystencjalnych dzisiejszego człowieka byłby - według diagnoz Greimasa - skutkiem osiągnięcia przez kulturę stanu takiego zautomatyzowania, który doprowadził do skrajnej konwencjonalizacji. Myśl strukturalistyczna i neostrukturalistyczna, ze swym deskryptywizmem, byłaby tu znamiennym signum temporis. Skoro właśnie w tym kręgu sytuuje się Greimasowska semiotyka-sujet, warto zwrócić uwagę na ważną właściwość, implicytnie, choć nie wprost zawartą w jej definicji. Otóż zarówno „ratio”, jak „logos” tłumaczymy jako „rozum”. Tym sposobem do definicja wkrada się element tautologiczności, przypominając nam, iż „twarda” koncepcja Greimasa, a osobliwie jego kwadrat semiotyczny, jest ujęciem wewnątrzsystemowym, pojmującym przedmiot - świat jako tekst do analizy, z pominięciem wiary w jego rzeczywisty byt. „W dziedzinie epistemologii naiwność wyszła z użycia”, skomentował tą postawę Claude Zilberberg ${ }^{10}$, deprecjonując realizm nie tylko epistemologiczny, ale i ontologiczny. Jakże daleko jesteśmy w tej chwili od kluczowego pierwiastka aksjologicznego!

Co istotne, nawet tak rygorystycznie usystematyzowana semiotyka strukturalistyczna nie unikała kłopotów, by tak rzec, praktycznych. Wynikały one na przykład z pojmowania przedmiotów jako „niedokończonych”, nawet u kresu analiz pozostających indeksami własnej zasady tworzenia. Przedmiot musiałby być więc ujmowany zarówno synchronicznie, jak i diachronicznie (jak ma to miejsce w odczytywaniu mitów przez Lévi-Straussa). W drugim z tych podejść punktem wyjścia byłby brak rozróżnicowania, po którym nastąpiłoby rozbijanie jedności i konstytuowanie się dualnych kontrastów.

\footnotetext{
8 R. Dorra, Oddech i sens, przeł. B. Paczyńska, w: Idac za Greimasem, wyd. cyt., s. 213.

9 J. Fontanille, I. Klock-Fontanille, Gniew: namiętność, grzech, forma życiowa, przeł. M. Loba, w: Idac za Greimasem, wyd. cyt., s. 114.

10 C. Zilberberg, wyd. cyt., s. 151.
} 
Te stwierdzenia można z powodzeniem odnieść do Sémiotique des passions. Opisywany tam stosunek podmiotu do świata zapośredniczony jest w sposób nieunikniony przez ciało. Analiza istoty oddechu daje pretekst, by ujrzeć w człowieku stworzenie dualistyczne - wdech i wydech, nabycie i utrata, koncentracja i rozproszenie. Jakkolwiek ciało - przedmiot postrzegany procesualnie, tj. w trakcie oddychania, w swych biologicznych pregnancjach byłoby charakteryzowane nieomal przez coniunctio oppositorum (materia/energia, ciągłość/segemntacja, etc.), metawniosek tu wyciągnięty pozostałby w obszarze dogmatycznego strukturalizmu. Nadawanie znaczenia własnościom zmysłowym możliwe jest tylko przy zachowaniu opozycji binarnych, stąd konieczność stałej ich obecności w analizie. Redukcja paradoksów czy dwuznaczności i zastąpienie ich dychotomiami to przecież element budowania scjentystycznej idealności w dyscyplinie.

O niedoskonałości skomponowane jest w odmienny sposób. Wejście na obszar estetyki literackiej eliminuje z wypowiedzi systematyczną naukową terminologię, jednak jej nie przekreśla. Eseje, bądź co bądź napisane przez (współ)autora Sémiotique. Dictionaire raisonné de la théorie du langage. Jeśli wolno przywołać określenie chętnie używane przez Umberta Eco, modelowy czytelnik O niedoskonałości ma być obeznany z Greimasowską siatką pojęciową, jednak konieczność ta uzasadniona jest głównie Wittgensteinowskim „Musi niejako odrzucić drabinę, uprzednio po niej się wspiąwszy" 11 .

Zatem w sferze epistemologicznej projekt nowej „estetyki niedoskonałości” $\mathrm{w}$ znacznej mierze usytuowany został na fundamencie pogrążonego w kryzysie pierwotnego programu.

Warto teraz uczynić pewną dygresję, i przypomnieć o wadze triady dobro - prawda - piękno. Przeminęła scholastyczna koncepcja ujmująca prawdę w formule: veritas est adequatio intellecto et rei, jak również rozumienie piękna jako perfectio et concordia, obie zresztą wywodzone od Tomasza Akwinaty. Jednak aby móc pozostać przy akceptacji terminów strukturalistycznych, za kontrę wobec klasycznej triady przypadałoby uznać zło - fałsz - brzydotę. Takie pojęcia należałoby nanieść na zachowujący postawę binarną, gwarantujący spójność systemu kwadrat semiotyczny ${ }^{12}$. Zostalibyśmy tym samym $\mathrm{w}$ granicach tego, co nazwałam pierwotnym projektem Greimasa, albowiem uznawał on w nim aksjologiczną naddeterminację. Wedle Seweryny Wysłouch, wartościowanie dotyczy

11 „To, co się uwidacznia, jest tym, co mistyczne.” (6.522); „Tezy moje wnoszą jasność przez to, że kto mnie rozumie, rozpozna je w końcu jako niedorzeczne; gdy przez nie - po nich wyjdzie ponad nie. (Musi niejako odrzucic drabine, uprzednio po niej się wspiąwszy.) Musi te tezy przezwyciężyć, wtedy świat przedstawi mu się właściwie." (6.54) - L. Wittgenstein, Tractatus logico-philosophicus, przeł. B. Wolniewicz, PWN, Warszawa 1970.

12 Za: A. Grzegorczyk, Estetyka niedoskonalości, w: Semiotyczne olśnienia, red. A Grzegorczyk, Humaniora, Poznań 1997, s. 135. 
większości prymarnych przeciwieństw znaczeniowych (jak dusza/ciało, indywidualny/zbiorowy) ${ }^{13}$. Tymczasem w O niedoskonałości nie mamy do czynienia z przywoływaniem tak pojmowanych opozycji elementów triady dobro - prawda - piękno. Ostatniej z tych kategorii dotyczy jedynie zasada symetrii i asymetrii w dziele sztuki. O problem prawdy zahacza z kolei rozróżnienie niedoskonałego jawienia się i doskonałego bytu. Jakkolwiek są to przeciwieństwa - a jako takie odczytujemy je ze wspomnianego schematu aksjologicznej naddeterminacji - rządzi nimi prawidłowość procesu: jawienie się jest podatne na zmianę, zdolne do ulepszania się.

Koniecznym krokiem na drodze do prawdy zapośredniczonej przez kategorię aisthesis byłoby niewypowiadalne doznanie zmysłowego piękna, jednak w semiotycznym dążeniu do głębi brak etapu przemiany! ${ }^{14}$ Interesujące jest tu odniesienie do mistycznej drogi na Karmel w aspekcie, uczynione przez Annę Grzegorczyk w Pracy sensu. Mianowicie właśnie owa droga uwzględnia przemianę jako niezbędną dla późniejszego osiągnięcia łaski dobra i piękna, a w końcu - świetlistej doskonałości. Ta uwaga stanowi ilustrację niewystarczalności i niepełności koncepcji nawet późnego Greimasa, niemniej jest tylko dygresją, i daleka jestem od postulowania przyjęcia przez semiotykę optyki mistyki chrześcijańskiej.

O niedoskonałości nie boi się wprowadzać semiotyki w obszary, który ona dotąd unikała: w etykę, w wymiar egzystencjalno-filozoficzny. W zbyt „usemantyzowanym" świecie, ów nowy projekt miałby znieść impas czyniący nadmiar znaczenia brakiem znaczenia poprzez zmianę znaków w gesty. Postulat takiego „zderzenia z rzeczywistością” wywołał swego rodzaju zwrot symboliczny. Pojęcie symbolu było w semiotyce strukturalistycznej przez bardzo długi czas „zakazane”. Obowiązywało jedynie proste rozgraniczenie, wedle którego symbol był umotywowany, a znak sensu stricto - arbitralny. (mankamenty takiego podejścia wskazał Tzvetan Todorov w swym Wstepie do symboliki ${ }^{15}$ ). Znak, na przykład językowy, to pośrednik umożliwiający ponadindywidualny przekaz, opowiadanie o ludzkim działaniu, u podstaw którego leży wszak według Paula Ricoeura doświadczenie symboliczne. Symbolizowanie, w takie sposób łączące się z egzystencją, miałoby wprowadzić do humanistyki udręczonej kulturą wyczerpania uzdrawiającą zasadę rzeczywistości. Co ciekawe, w estetyce niedoskonałości ów akces dokonuje się zgodnie z proponowanym przez Rolanda Posnera opisem mechanizmu semiotycznego systemu kultury. Składają się na niego cztery sfery:

13 Za: S. Wysłouch, Magiczny kwadrat Greimasa, w: Semiotyczne olśnienia, wyd. cyt., s. 92.

14 Odwołuję się tu do schematu przedstawionego przez A. Grzegorczyk w Pracy sensu, s. 13.

15 T. Todorov, Wstęp do symboliki, w: Symbole $i$ symbolika, wybór i wstęp: H. Markowski, Czytelnik, Warszawa 1990. 
- Obszar pozakulturowy, który uczestnikom danego społeczeństwa jest zupełnie nieznany

- Obszar pozakulturowy, który przez uczestników danego społeczeństwa pojmowany jest jako przeciwstawny własnej kulturze

- Obszar peryferii kulturowej, który przez uczestników jest, co prawda, uznawany, lecz nie jest pojmowany jako centralny dla danej kultury oraz

- Obszar kulturowego centrum, który jako taki jest akceptowany i rozumiany jako odgrywający istotną rolę dla tożsamości danej kultury ${ }^{16}$.

Następnie autor objaśnia sposób, w jaki może dokonywać się wprowadzenie jakiegoś elementu ze sfery kulturowej peryferii do centrum: oto musi zwiększyć się dystrybucja kodu danego elementu (opanowanie kodu przez większą ilość uczestników kultury), frekwencja użycia oraz - co wydaje się najważniejsze - prestiż. Wedle tego schematu zaszło wprowadzenie w obszar semiotyki rozważań nad symboliką, a dokonało się to ze szczególnym uwzględnieniem wzrostu oceny wartości poznawczej tematyki.

Warto tu odnotować problem, który Posner pomija. Byłaby nim prawomocność jakiegokolwiek definiowania lub wyznaczania centrum i peryferii, albowiem współcześnie mamy do czynienia z afirmacją indywidualnych semioz. Być może zamiast odwołań do przekonań członków społeczeństwa, lepiej byłoby przyjać, iż konsensus wyznaczany jest przez prawa danego systemu semiotycznego ${ }^{17}$.

O niedoskonałości włącza symbole w obszar rozważań semiotycznych za pośrednictwem kategorii aisthesis. Należy jednak pamiętać, że nie było to pierwsze podejście do problematyki. Już niemal ćwierć wieku temu Umberto Eco zwrócił uwagę, iż semiotyczny dylemat dotyczący symboli nie sprowadza się do metodologii czy tym bardziej - terminologii. Formułując przedmiot swych naukowych poszukiwań, określił znaki nie jako mechaniczne „nośniki” danego przekazu, a jako mówiące o innych znakach „powiązanych nie kończącym się łańcuchem dostojnych systemów symboli, dla których i poprzez które człowiek utracił w ciągu wieków kontakt z rzeczami - zakładając, że rzeczy istnieją naprawdę, a przyznaję, iż myśl ta dość mi się podoba - gdyż wydały się one już ujarzmione przez kulturę, a zatem przełożone na język znaków i językiem tym nazwane (...)"18. Autor oczywiście nie ograniczył się do tej krótkiej, nawiasem niemal uczynionej

16 Za: M. Fleischer, Teoria kultury $i$ komunikacji. Systemowe $i$ ewolucyjne podstawy, przeł. M. Jaworowski, Dolnośląska Szkoła Wyższa Edukacji Towarzystwa Wiedzy Powszechnej, Wrocław 2002, s. 83. Osobnym zagadnieniem byłoby konkretne zdefiniowanie centrum i peryferii, czy też wyznaczenie limesu między kulturowym a pozakulturowym.

17 Por. niżej, przypis 30.

18 U. Eco, Utajona obsesja średniowiecza, przeł. A. Wasilewska, „Literatura na świecie”, 1983, nr 7, s. 105. 
uwagi (która pochodzi z noty autobiograficznej). Znaczną część Semiotyki i filozofii języka poświęcił kwestii tak zwanego trybu symbolicznego ${ }^{19}$. Odrzucił tam Peirce'owskie pojmowanie symbolu jako jednego z rodzajów znaków, konwencjonalnego i arbitralnego. Symbol ma być bowiem nieskodyfikowany i aintelektualny, nie ma denotować, a odnosić się do „mgławicy znaczeń”, której rozpiętość wyznaczona jest kompetencją kulturowej encyklopedii odbiorcy ${ }^{20}$. Brak tu reguł semantycznych podsuwających prawidłową interpretację ${ }^{21}$. Jeśli - jak twierdzi Eco - związek symboliczny jednoczy formę i niewyrażalną treść, musi istnieć rzeczywistość pozasystemowa ${ }^{22}$. Znamienne jest odnalezienie takiego wątku właśnie w koncepcjach Umberta Eco, który przez swój „semiotyczny autograf” pod Imieniem róży („Stat rosa pristina nomine, nomina nuda tenemus”) postrzegany był raczej jako nominalista, aniżeli realista. Zaskoczenie zmniejsza jednak fakt, iż autor ten zawsze starał się łączyć dwa nurty w semiotyce - pochodzący od de Saussure'a i zapoczątkowany przez Peirce'a. Od dawna myśl Umberta Eco oskarżana jest o wikłanie się w niekonsekwencje, a w spojrzeniu diachronicznym, nawet w sprzeczności. Uchylę się od powtórzenie argumentów broniących włoskiego semiotyka. Niemniej jednak, pamiętając o uwagach uczynionych wcześniej, nie sposób uniknąć wrażenia, iż jego koncepcje dziś niejako wygrywają. Oczywiście Eco nie jest już tak wpływowy, jak niegdyś - być może dlatego, że mówi rzeczy niepopularne.

Od dziesięcioleci Eco para się działalnością publicystyczną, często sytuowaną na marginesie jego „właściwej” pracy. Takie umiejscowienie uważam za niesłuszne, a przynajmniej za niesprawiedliwe. W okolicznościowych felietonach lub esejach autor zwykle daje dowody przenikliwości swego spojrzenia na rzeczywistość, a uprzystępnienie formy dyskursu (dyskurs rozumiany po Greimasowsku, jako zaktualizowany przez użycie język) świadczy po prostu o pisarskiej sprawności i pozostaje kwestią retoryczną, nie merytoryczną. Przy lekturze tekstów takich, jak na przykład Więcej kanałów niż żeglarzy albo Święte wojny, pasja i rozum, nietrudno wysunąć oskarżenie o „nienaukową” ideologizację. Pamiętajmy jednak, że podobne zarzuty w swoim czasie wysuwał Greimas wobec Barthesa (gdy autor ten pisał o kodyfikowaniu symbolu, który, skonwenconalizowany, staje się ośrodkiem manipulacji i władzy, narzędziem kontroli społecznej). Zresztą Eco wolę, „aby

19 U. Eco, Symbol, w: tegoż, Semiotics and the Philosophy of Language, Macmillan, London 1984.

20 Por. przykład koła od wozu nad drzwiami wiejskiego domu w: U. Eco, Symbol, wyd. cyt., s. 162 .

21 Tamże, s. 137.

22 Więcej na ten temat w: A. Grzegorczyk, Filozofia nieoczekiwanego, Humaniora, Poznań 2002, zwł. s. 261-281. 
ujarzmić symbol i nadać mu znaczenie uspołeczniające" 23 widzi już we wczesnym średniowieczu, w neoplatonizmie i w hermetyzmie. Tymczasem dzisiejsza semiotyka, chcąc zachować rację bytu, musi ulec przekształceniu, niekoniecznie poprzez zwrot symboliczny; wystarczy na początek, by uprzywilejowanie denotatywności ustąpiło konotatywności. Praktyczną ilustracja takiego podejścia jest pozornie banalny i „przyjemny” tekst Kłamliwy język u Manzoniego w zbiorze Między klamstwem a ironia ${ }^{24}$. W nim to Eco dokonuje rekonstrukcji semiotyki zawartej implicytnie w najsłynniejszej włoskiej powieści, Narzeczonych. Przekonuje, iż jej autor, Alessandro Manzoni, manifestował nieufność wobec konwencjonalnej i arbitralnej semiozy, wyrażającej się w kłamliwych słowach i piśmie, i opowiadał się za semiozą naturalną, umotywowaną, nieintencjonalną, którą Eco określa jako „ludową". Paradoksem byłoby dowodzenie jej triumfu nad językiem werbalnym „za pomocą słowa powieściowego" 25. Autor Imienia róźy rozwiązuje ten dylemat przez odwołanie do retorycznego zabiegu hipotypozy. Zatem Narzeczeni jawią się „jako pewien rodzaj jezzykowej maszynerii, próbującej ożywić za pośrednictwem języka znaki niewerbalne: językowi towarzyszące, wyprzedzające go i otaczające w swej instynktownej i gwałtownej autonomii" ${ }^{26}$. To ostatnie określenie niemal na zasadzie metonimii przywołuje tryb symboliczny, jaki autor zdefiniował w Semiotyce $i$ filozofii języka. Analizowana powieść stanowi we włoskiej kulturze literackiej swoisty odpowiednik polskiego Pana Tadeusza, jednak rozważania prezentowane przez Eco są jak najbardziej współczesne, zgodne z dzisiejszym stadium rozwoju myśli semiotycznej.

Nie sposób określić, czy Greimas, gdyby życia starczyło, podjąłby jeszcze drogę obraną w O niedoskonałości, a tym bardziej, dokąd mógłby dojść. Faktem jest jednak, iż droga tą nie podążyli jego uczniowie. Oto bowiem najchętniej kontynuowany jest scjentystyczny aspekt myśli autora Du sens. Osobnym problemem są glossy do Greimasowskiej estetyki niedoskonałości i próby zrozumienia semiotycznego przesłania Mistrza. Symptomatycznym esejem jest Semiotyk i jego sobowtór Erica Landowskiego. Przede wszystkim autor utrzymuje przekonanie o zupełnym braku dostępu do rzeczywistości jako siedziby bytu ${ }^{27}$. (Podobnie u Buchera, słowa „rzeczywistość” i „świat zewnętrzny” pisane są w cudzysłowiu). W konsekwencji tego podmiot okazuje się w sposób nieunikniony schizofreniczny. („O prawdziwym Ja nic substancjalnego nie może być powiedziane, ponieważ jeśli istnieje,

23 U. Eco, O symbolu, w: tegoż, O literaturze, przeł. A. Wasilewska, Muza, Warszawa 2003, s. 139 .

24 U. Eco, Między klamstwem a ironia, przeł. M. Woźniak, Wydawnictwo M, Kraków 2004.

25 Tamże, s. 57.

26 Tamże, s. 58.

27 E. Landowski, Semiotyk i jego sobowtór, w: Idac za Greimasem, wyd. cyt., s. 262. 
$\mathrm{z}$ definicji transcenduje ono $\mathrm{w}$ swoim byciu przypadkowe przejawy widzialnego Ja”, „bez względu na swe wysiłki czynione w celu odsłonięcia swej »autentycznej « tożsamości, podmiot w rzeczywistości będzie mógł tylko pomnażać konkretne formy swego jawienia się" 28 ).

Ponadto mnożą się konstrukty teoretyczne, na przykład język jako Trzeci pomiędzy mną (choćby jedynie jawiącym się) a adresatem dyskursu - mych słów. W takim ujęciu język nie jest systemem zewnętrznym wobec jednostek, jakkolwiek im narzucanym (lacanowskie "La langue nous parle”) - tu do systemu należy wszystko. Podobne konstatacje budzą uzasadniony sprzeciw, tym dobitniej pokazując, iż semiotyka strukturalna już „za Greimasa” doszła do kresu swych możliwości.

Problemów o podobnym charakterze nie uniknął bynajmniej nurt po-Peirce’owski. Współczesna semiotyka triadyczna zakłada, iż wszelkie poznanie i myśl możliwe są jedynie w znakach i poprzez znaki, nie istnieje zatem poznanie bezpośrednie (niezapośredniczone przez znaki). Dotyczy to również podmiotu - poznaje on siebie jako znak, albowiem żaden inny sposób nie jest mu dostępny. Posuwając się dalej, przyjmuje się, iż istota ludzka jest znakiem - oczywiście nie prostym nośnikiem sensu, tylko złożonym i dynamicznym „procesem ogarniającym wszystkie trzy ontologiczne modalności, tj. [peirce'owskie] Pierwsze, Drugie i Trzecie”, wszystkie semiozy zachodzące „w przestrzeni indywidualnej podmiotowości” 29. Jako byt znakowy, jednostka istnieje dzięki praktykom dyskursywnym, instytucjonalnym i ideologicznym, które wyznaczają jej miejsce społeczne (wszak, jak przypomina Kalaga, „systemy semiotyczne są rezultatem hierarchicznego konsensusu wspólnoty" ${ }^{30}$ ), a poprzez akumulacje i interpretacje relacji z uprzednimi interpretantami i semiozami, jakie jej dotyczyły, zachowuje ciągłość. Homo textualis, ów podmiot - znak obok tego, że jest wciąż interpretowany, dokonuje również interpretacji świata i samego siebie. Interpretacja jest tu rozumiana jako pochodna poznania i rozumienia, określająca związki przedmiotów i znaków w kulturze.

Idąca za tą praktyką, konieczność budowania hierarchii i wartościowania czyni podmiot etycznym. Jednak także i ta koncepcja nie wykracza poza ujęcie systemowe, skoro podmiot tkwi w dyskursie - aktualizowanym języku. Wedle Martina Heideggera „w języku jako mediacyjnym systemie znaków ujawnia się rzeczywistość" ${ }^{31}$, jednak pamiętajmy, iż jawienie się jest przeciwstawne bytowi!

\footnotetext{
28 Tamże, s. 261.

29 W. Kalaga, Mglawice dyskursu, Universitas, Kraków 2001, s. 273. Autor odwołuje się tu do Peirce'owskiego rozstrzygnięcia przypisującego trzem elementom znaku: nośnikowi, przedmiotowi dynamicznemu oraz interpretantowi, następujące modalności ontologiczne, odpowiednio: jakość, przedmiot materialny i ideę.

30 Tamże, s. 130.

31 Za: tamże s. 52.
} 
Interesującą egzemplifikację tego zagadnienia podsuwa nam - znów - Umberto Eco, tym razem jako beletrysta. W jego ostatniej powieści, zatytułowanej Tajemniczy płomień królowej Loany ${ }^{32}$, czytamy o egzystencjalnym zagubieniu Yamba, erudyty o „pamięci z papieru”. Obszerność problematyki i ramy niniejszego artykułu nie pozwalają jednak na rozwinięcie tego tematu.

Po tej dygresji tym zasadniejsze jest pytanie: Czy zwrot symboliczny, prawdziwe otwarcie na rzeczywistość i rezygnacja z bezwzględnej naukowej ścisłości przekształcą semiotykę tak, iż utraci ona swą „tożsamość”? Pewnym jest, że chcąc nadal rościć sobie prawo do kompleksowego opisu kultury, zmianom ulegać musi.

32 U. Eco, Tajemniczy płomień królowej Loany. Powieść ilustrowana, przeł. K. Żaboklicki, Noir Sur Blanc, Warszawa 2005. 